This item was submitted to Loughborough's Research Repository by the author.

Items in Figshare are protected by copyright, with all rights reserved, unless otherwise indicated.

\title{
Design management in practice: testing a training initiative to deliver tools
} and learning

PLEASE CITE THE PUBLISHED VERSION

PUBLISHER

(C) Emerald

LICENCE

CC BY-NC-ND 4.0

REPOSITORY RECORD

Bibby, Lee, Dino Bouchlaghem, and Simon A. Austin. 2019. "Design Management in Practice: Testing a Training Initiative to Deliver Tools and Learning". figshare. https://hdl.handle.net/2134/3871. 
This item was submitted to Loughborough's Institutional Repository (https://dspace.lboro.ac.uk/) by the author and is made available under the following Creative Commons Licence conditions.

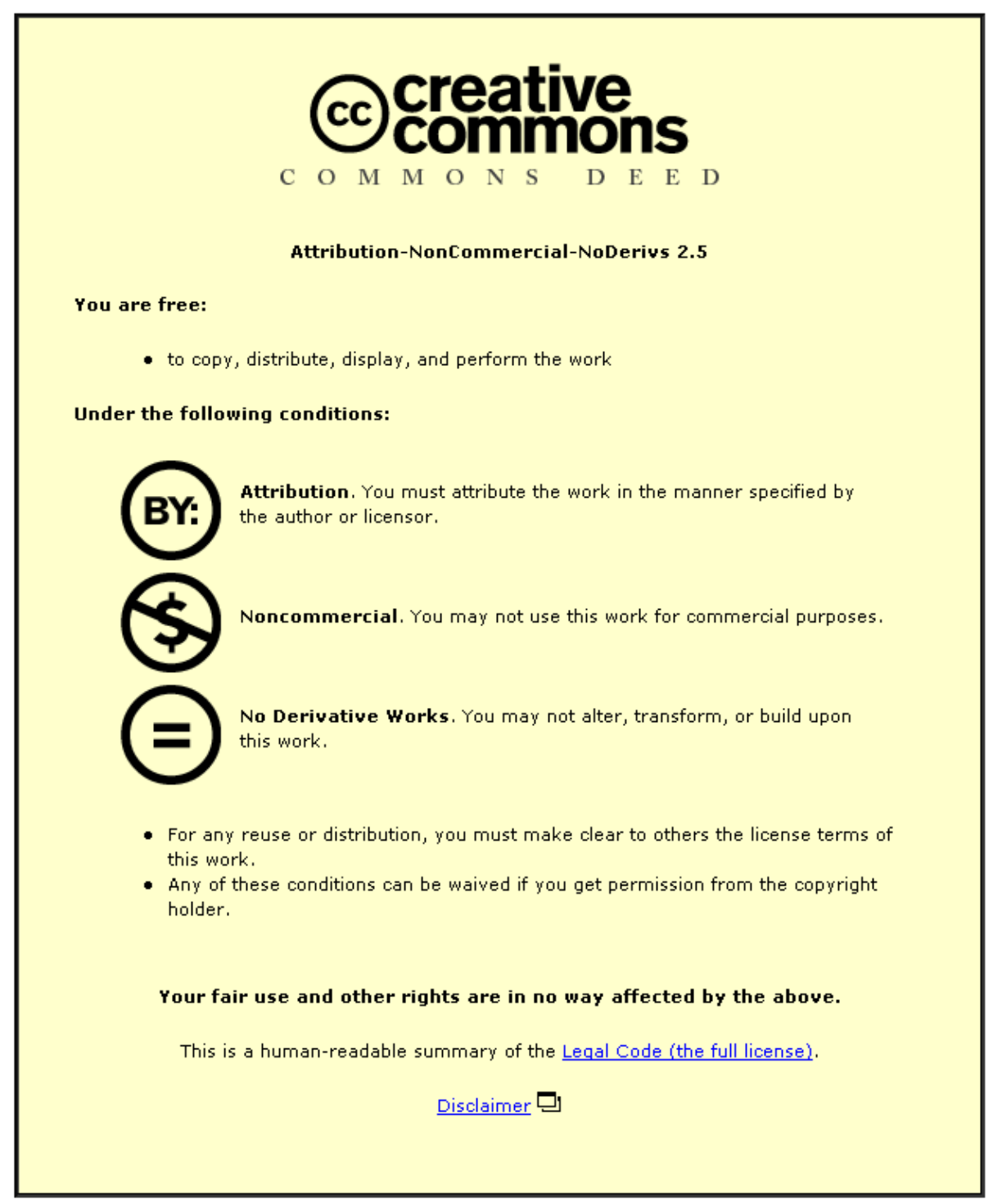

For the full text of this licence, please go to: http://creativecommons.org/licenses/by-nc-nd/2.5/ 
DESIGN MANAGEMENT IN PRACTICE: TESTING A TRAINING

INITIATIVE TO DELIVER TOOLS AND LEARNING

Principle Author: Lee Bibby

Co-authors: Dino Bouchlaghem, Simon Austin

\section{Lee Bibby}

Centre for Innovative Construction Engineering, Loughborough University

Contact Information:

Centre for Innovative Construction Engineering,

Department of Civil and Building Engineering,

Loughborough University, Leicestershire,

LE11 3TU

Tel: $\quad+44(0) 7970704772$

Tel 2: $+44(0) 1295269141$

Email: lee.bibby@skanska.co.uk

\section{Dino Bouchlaghem and Simon Austin}

Loughborough University, Department of Civil and Building Engineering 


\begin{abstract}
Drives to improve industry performance are being hindered by difficulties in managing the construction design process and preventing the UK construction industry from delivering projects on time, to budget and to the specified quality. The paper reports on a research project at a major UK civil and building design and construction company to develop and deploy a training initiative capable of making significant improvements to its design management performance and deliver benefits to many project stakeholders. It describes the development, content and trialing of the training material and a suite of twenty-five design management tools to drive change throughout the organisation. The paper is likely to be of interest to those involved in design management and the development of tools and practices to help the industry improve design management performance.
\end{abstract}

Keywords: construction, design, management, industry practice, process, tools.

\title{
INTRODUCTION
}

In recent years efforts to improve its performance the UK construction industry has shown an increasing interest in management of the design process and its integration with other project processes. One catalyst has been Egan et al (1998), who stated that to deliver greater value to its clients 
the design, procurement and construction operations need to be an integrated process. As design and build type projects are seen as a means to bring the processes together (Moore and Dainty, 1999) the private finance initiative (PFI) and design and build (D\&B) procurement strategies have become widely used in recent years. This trend is unlikely to falter. The UK Government, as major industry client now assumes that some form of D\&B procurement will be used on its projects unless a compelling case can be made for using a traditional procurement route (Office of Government Commerce, 2002). Furthermore, recent targets set by the Strategic Forum for Construction aim to increase the use of integrated project teams and supply chains to $20 \%$ of projects (by value) by end of 2004 , rising to $50 \%$ by end 2007 (Egan et al, 2002).

As a result of the drive away from traditional procurement routes contractors have found themselves with an increasing responsibility for control of a process they have had little experience in managing. They now have to adapt accordingly. The learning curve is steep, not least because many projects must now be delivered fast track while co-ordinating an increasingly complex fabric and content of buildings (Austin et al, 1996). In an effort to accelerating this learning both industry leaders and SMEs have collaborated in projects that aim to manage the integration of teams during the design phase such as the Analytical Design Planning Technique (Austin 
et al, 1999), Integrated Collaborative Design (Austin et al, 2001), and Teamwork2000 (Business Round Table, 2002). Clearly, management of the project team during the design phase is a key issue for the UK construction industry which organisations must address.

A top four civil and building design and construction company with interests in PFI, Prime Contracting, D\&B as well as traditional contracting is adapting to the changing UK construction market. For the past three years, through a partnership with Loughborough University and the Engineering and Physical Sciences Research Council (EPSRC), it has been addressing its approach to design management. A training initiative has developed out of this partnership to deliver critical thinking on design management and a suite of twenty-five tools. This paper describes the development, content and trialing of the initiative within the organisation.

While the training initiative was undertaken to suit the needs of a major D\&B contractor, its development was influenced by best practice within and outside the industry, as well as common barriers identified in literature (Bibby et al, 2002). Hence, the lessons learned from work reported in this paper should be widely applicable to those in the industry involved in design management and the development of tools and practices to help the industry improve design management performance. Whilst the findings are 
based on a single organisation, the work carried out represents a significant step forward for the industry in developing strategies to deliver improvements to design management performance.

\section{RESEARCH METHODOLOGY}

The research presented in this paper sought to establish and test a training initiative capable of teaching the employees of a major UK contractor how to effectively manage the design process. The methodology comprised: a state of the art review to prepare the training initiative; a review workshop; and a questionnaire and structured interviews to investigate the effectiveness of the dissemination in changing current practice.

The state of the art review guided the format of the initiative by identifying similar work in the construction industry. It also helped shape the content by providing an up-to-date understanding of design management, the barriers that must be addressed and revealed source material from which practices and tools were developed.

The review workshop was held over two days at a hotel near London with the purpose of assessing the format and content and delivery of the training initiative. Fourteen company employees (seven design managers; four project managers; two commercial directors and one planning manager) 
with a particular interest in design management were selected to take part. A week prior to the workshop each attendee was provided with a copy of the design management handbook for review. The proposed training material was presented section-by-section in the workshop and then critically appraised in terms of the effectiveness of the delivery and user friendliness of the tools and practices._Comments made by workshop attendees were recorded for later compilation and analysis with questionnaire results.

The structured questionnaire prepared following good practice (Race, 2001; Fellows and Liu, 1997) was issued to collect more detailed views of the workshop attendees on the content and delivery of the training initiative. It was issued after the review workshop with returns requested three weeks later. This allowed attendees some time to reflect on the content and delivery of the design management handbook and training workshop. Twelve of the fourteen (86\%) workshop attendees returned completed questionnaires.

The questionnaire asked respondents to rate aspects of the training initiative using a five point rating scale. They were also given the opportunity to make open comments on each aspect of the training initiative. The results were compiled with the comments made during the review workshop to 
establish whether the training initiative was capable was capable of disseminating effective design management practice.

Approximately 300 personnel, covering all project team members (construction, procurement, commercial and design), are receiving training on the critical aspects of design management and their involvement in the process. Design managers are receiving additional training on the operation and implementation of the suite of design management tools. The company and research team believe it is vital that the training is given to all the management teams. In order to succeed, design management requires a range of professionals to collaborate and a significant barrier to this is a lack of understanding of the motives and actions of others. If professionals that work with design managers understand the process of design, key barriers to design management and the actions of the design manager, then they should be better able to support the design manager and manage the design process collaboratively.

\section{WHY A TRAINING INITIATIVE?}

Research to improve design management performance of a major UK construction company has required many questions to be answered. The first was: "Is a training initiative the right way to improve design management in the organisation?” Previous research (Bibby et al, 2002) established that the 
understanding of the very nature of the design process had to be improved and employees provided with practical tools to manage the process.

Therefore, a training initiative, which provided such tools and learning, was seen as the most appropriate means to improve design management within the company.

\section{WHAT MAKES PRACTITIONERS PARTICIPATE IN TRAINING?}

The training initiative must be capable of motivating practitioners to adopt new practices and tools presented in the initiative, because without this desire the material would never be successfully implemented (Heath, Scott and Boyland, 1994). Therefore, barriers that exist to the implementation of new tools in the construction industry must be addressed by the training content and format. There are many criticisms levelled at design management tools developed for industry. They are fragmented, insufficiently developed, poorly deployed and couched in abstract terms. Moreover, as they often show an overly complex representation of industry practice they are not focused on pragmatic outcomes and force an unwanted discipline on practitioners. (Freire and Alarcon, 2000; Frost, 1999). Knowledge of such difficulties was central to the production of an effective, user-friendly and pragmatic training initiative that would motivate practitioners. 


\section{WHAT SHOULD THE TRAINING CONTAIN?}

There were several issues that had to be considered when collecting training material. Previous research (Bibby et al, 2002) had identified five key improvement issues that the company must address to improve design management performance (structured and explicit design process; improved design planning; integrated design and construction; information flow management and ability to understand / predict impact of design changes). It was also important to motivate practitioners to use new practices and tools and be realistic about what each can achieve. Therefore, literature collection was based on four key areas: design management tools; effective ways of managing the process; benefits; and barriers to design management. Collecting information in this way ensured that it was direct, concise and relevant.

\section{HOW SHOULD TRAINING BE PRESENTED?}

Discussions were held with the organisation to establish an appropriate means of presenting the wealth of collected material. It was decided that the core of the initiative should be a handbook or manual containing practical ideas and tools that could be easily implement. However, the company and research team felt that this alone would be insufficient to bring about significant change and therefore the handbook was supported by a training workshop disseminating the tools and ideas to the company employees. 


\section{A Design Management Handbook}

The outputs of similar projects (Thomson and Austin, 2001; Austin et al, 2001) were consulted to help present the content in a user friendly format. From this review the core format of the handbook was created: ten chapters each covering a critical aspect of design management practice followed by a suite of twenty-five design management tools (Table 1). A design management tool is assumed to be any procedure, standard document or schedule that could support the management of the design process. The tools were grouped into four distinct yet inter-dependent categories: planning, co-ordination, development and monitoring to help identify where and when they should be applied: planning tools help the strategic planning of activities and information flows;co-ordination tools the daily management of activities and information; development tools help prepare a value-focused design that meets stakeholder requirements; and monitoring tools help check that design activities and information flows are occurring as planned and to plan corrective action when progress is behind programme. 


\begin{tabular}{|c|c|c|}
\hline handbook section & topics covered & tools provided \\
\hline $1 \quad$ Design management & $\begin{array}{l}\text { The need for and what is design } \\
\text { management? } \\
\text { Nature of the design process } \\
\text { Why current design management goes } \\
\text { wrong } \\
\text { How can we better manage the design } \\
\text { process? }\end{array}$ & \\
\hline 2 The design process & $\begin{array}{l}\text { Nature of the process } \\
\text { Involve parties at the right time } \\
\text { allow adequate design time } \\
\text { Engender common design process }\end{array}$ & \\
\hline $\begin{array}{ll}3 & \text { Stakeholders objectives, briefs and } \\
\text { tasks }\end{array}$ & $\begin{array}{l}\text { The need to, barriers to and incorporating } \\
\text { stakeholder needs in the design }\end{array}$ & $\begin{array}{ll}\text { P01 } & \text { Brief document } \\
\text { P02 } & \text { Concept design kick-off meeting } \\
\text { P03 } & \text { Scheme design kick-off meeting } \\
\text { P04 } & \text { Detailed design kick-off meeting }\end{array}$ \\
\hline $4 \quad$ Managers and structures & $\begin{array}{l}\text { The need for, barriers to, qualities of and } \\
\text { training good design managers } \\
\text { suitable organisational structure }\end{array}$ & P010 Design manager job description \\
\hline $5 \quad$ Selecting team members & $\begin{array}{l}\text { Importance of the team, necessary } \\
\text { relationships and attitudes, skills and } \\
\text { competencies }\end{array}$ & $\begin{array}{ll}\text { P07 } & \text { Consultant benchmarking } \\
\text { P08 } & \text { Consultant interviews }\end{array}$ \\
\hline $\begin{array}{ll}6 & \text { Planning the design process }\end{array}$ & $\begin{array}{l}\text { The need for, barriers to and planning the } \\
\text { design process }\end{array}$ & $\begin{array}{ll}\text { P06 } & \text { Master design programme } \\
\text { P09 } & \text { Discipline design programme }\end{array}$ \\
\hline $\begin{array}{ll}7 & \text { Ensuring design delivery }\end{array}$ & $\begin{array}{l}\text { The need for, barriers to and effective } \\
\text { design delivery }\end{array}$ & $\begin{array}{ll}\text { C01 } & \text { Information transfer schedule } \\
\text { C02 } & \text { Work package document } \\
\text { C03 } & \text { Co-ordination meeting } \\
\text { M01 } & \text { Progress report } \\
\text { M02 } & \text { Progress meeting }\end{array}$ \\
\hline 8 Managing information flow & $\begin{array}{l}\text { The need for, barriers to and effective } \\
\text { information flow management }\end{array}$ & \begin{tabular}{|ll} 
C04 & Design workshop \\
C05 & Staged information delivery \\
C06 & Fix information \\
C07 & Interface schedule
\end{tabular} \\
\hline $9 \quad$ Developing the design & $\begin{array}{l}\text { Barriers to and the process of design } \\
\text { development }\end{array}$ & $\begin{array}{ll}\text { D01 } & \text { Value analysis } \\
\text { D02 } & \text { Brainstorming } \\
\text { D03 } & \text { Decision matrix } \\
\text { D04 } & \text { Task force meeting } \\
\text { D05 } & \text { Design review document } \\
\text { D06 } & \text { Design proposal document }\end{array}$ \\
\hline 10 Design changes & $\begin{array}{l}\text { The effect of, barriers to and managing } \\
\text { design change proposals }\end{array}$ & P05 Design change workshop \\
\hline
\end{tabular}

Table 1: Design management handbook contents 
The handbook chapters have a standard format (Figure 1), each containing a "challenge" and "objective”. The former indicates the importance of the subject area and the latter explains what the reader should learn and be able to achieve. Each chapter also contains a list of relevant tools. These features aim to motivate practitioners to read the chapters and adopt ideas presented by highlighting practical benefits.

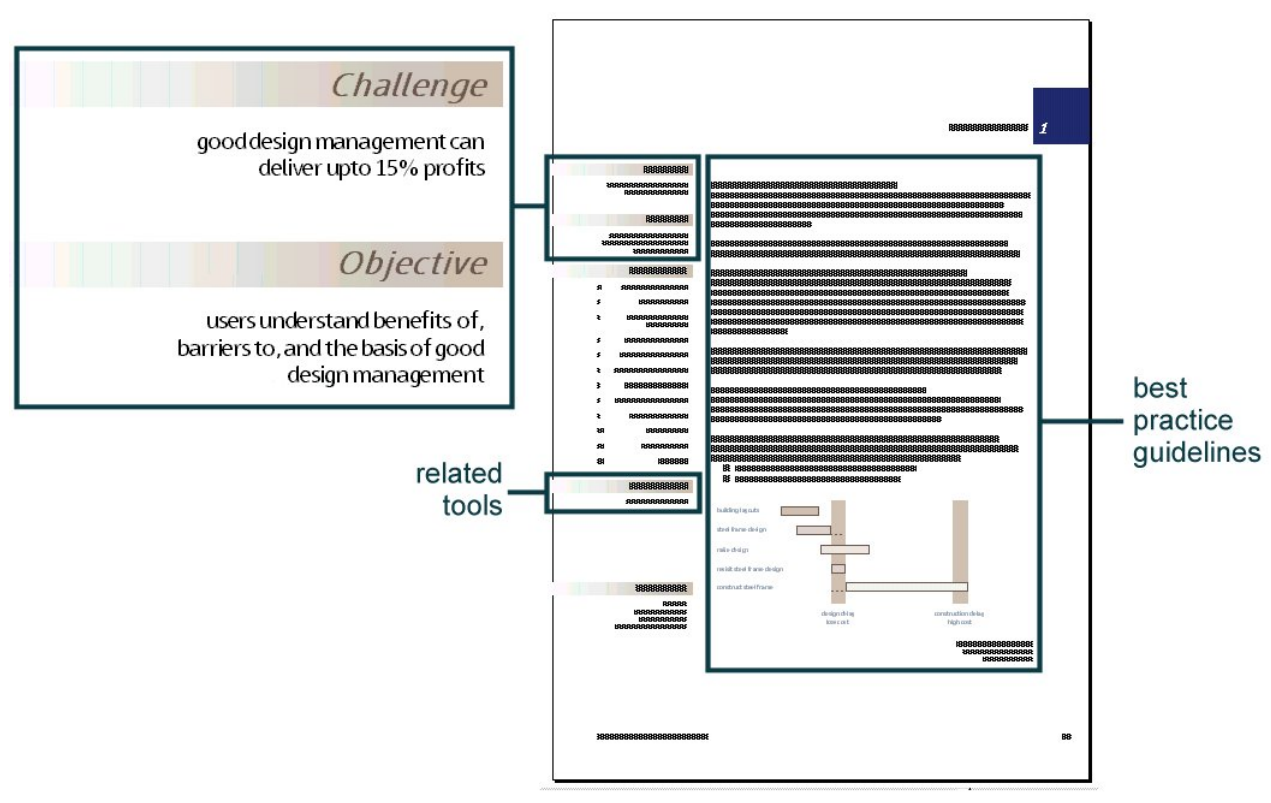

Figure 1: Handbook chapter page format

The design management toolsheets were also standardised to aid reference, comparison and selection of tools. The standardised format also helped ensure a complete tool was presented to practitioners. Many techniques identified in the literature were incomplete and lacked the detail that is necessary for application. For example, some have academic language, 
unclear process steps, and did not explain who should use them or when they should be applied. Others lacked supporting documents such as examples and blank templates., The standard format was very useful in helping modify and expand the content to provide comprehensive and practical tools suited to the needs of industry. The toolsheet sections and the reasons for their inclusion are shown in Figure 2, together with examples of tool pages in Figures 3 and 4.

\begin{tabular}{|l|l|}
\hline toolsheet section & \multicolumn{1}{|c|}{ reason for inclusion } \\
\hline Objectives & $\begin{array}{l}\text { Describes the intended purpose of the tool so users are clear of what the } \\
\text { tool will help them achieve. }\end{array}$ \\
\hline Pre-requisites & $\begin{array}{l}\text { Describes documents and information required to apply the tool. This } \\
\text { helps to ensure users are able to use the tools without delay. }\end{array}$ \\
\hline Related tools & $\begin{array}{l}\text { Identifies other practices linked to the tool. Synergies between any tools } \\
\text { are clearly identified to address concerns that many design management } \\
\text { tools are fragmented (Freire and Alarcon, 2000). Ensures the toolbox is } \\
\text { co-ordinated and coherent. }\end{array}$ \\
\hline Further information & $\begin{array}{l}\text { Research team contact information. Users are able to contact the team if } \\
\text { they have queries relating to application of the tool. }\end{array}$ \\
\hline Summary & $\begin{array}{l}\text { Short overview outlining what the tool does, where it is used and method } \\
\text { of use. This way, users are clear on where and when to use the tool. }\end{array}$ \\
\hline Benefits and barriers & $\begin{array}{l}\text { Describes the benefits that practitioners should expect from using the } \\
\text { tool, and barriers they should be aware of that may affect its } \\
\text { performance. This section aims to help motivate practitioner to use the } \\
\text { tool and also be able to remove barriers to its application. }\end{array}$ \\
\hline Procedure & $\begin{array}{l}\text { Detailed description of the activities needed to apply the tool. This makes } \\
\text { the operation of the tool transparent (Frost, 1999), easing their } \\
\text { application into practice. }\end{array}$ \\
\hline Flowchart & $\begin{array}{l}\text { Abbreviated representation of the procedure in flowchart format. It } \\
\text { summarises the key application stages of the tool. This is for users who } \\
\text { have become familiar with the tool and need only check the outline } \\
\text { procedure. }\end{array}$ \\
\hline $\begin{array}{l}\text { Additional documentation to help users familiarise themselves with the } \\
\text { tools and apply them in practice. These include templates, examples and } \\
\text { electronic versions of the tools. Inclusion of such material is necessary } \\
\text { for practitioners to adopt new tools (Frost, 1999). }\end{array}$ \\
\hline
\end{tabular}

Figure 2: Tool standard format 


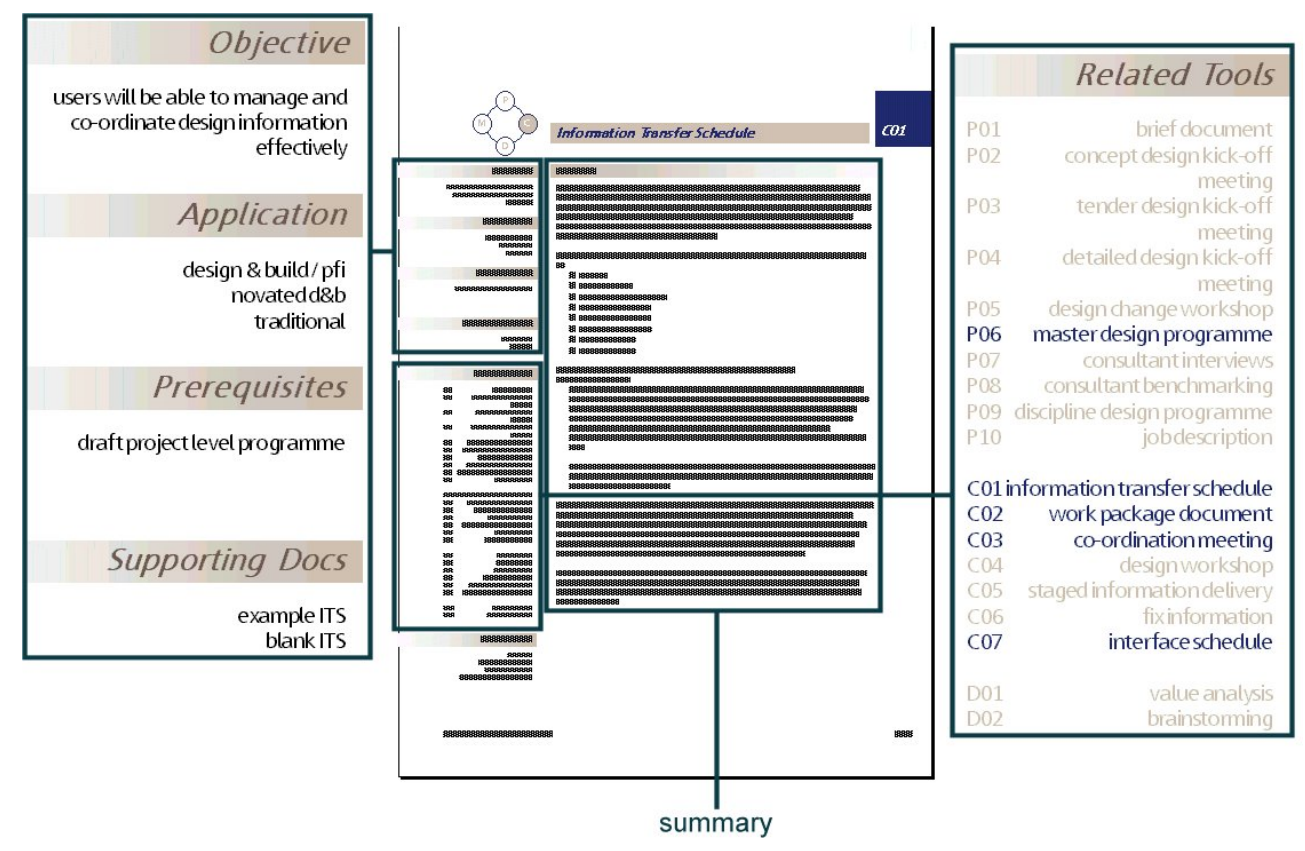

Figure 3: Tool front page format

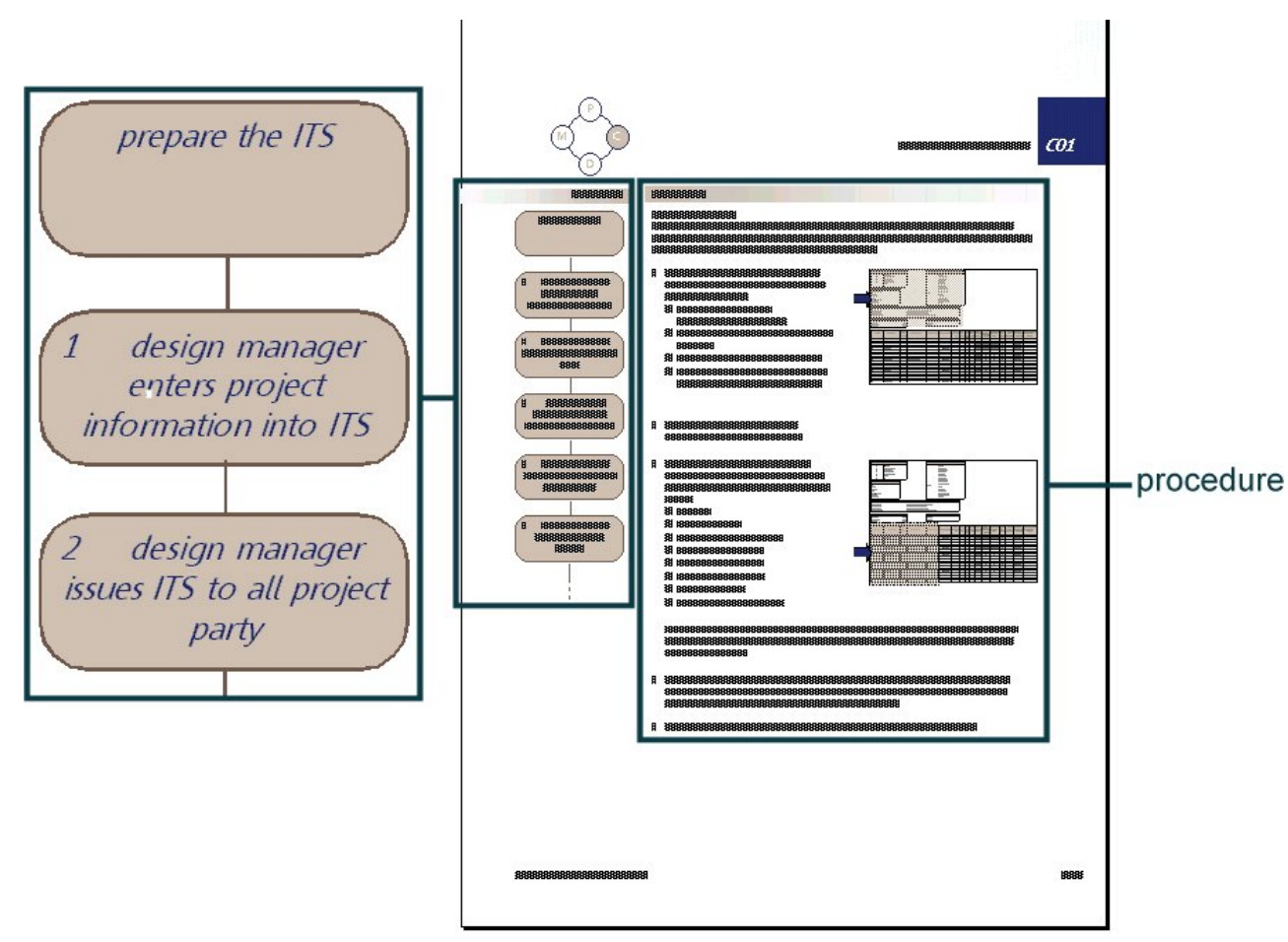

Figure 4: Tool procedure and flowchart 
A set of four tool selection tables (one for each tool type) was also provided in the handbook to help practitioners select tools appropriate for their needs by referring to objectives they wish to achieve or problems they wish to overcome. The tables were designed to help individuals who recognise the problems and issues of managing the design process but are uncertain how they should resolve them.

\section{A Training workshop}

The ideas, practices and tools contained in the handbook were developed into ten training modules each relating to a chapter in the handbook. The workshop material is delivered using a combination of techniques to maintain commitment and interest, including presentations, discussions, worked examples and problem solving exercises. This allows trainees the opportunity to discuss the barriers to design management, how to improve and to become familiar through worked examples and exercises. This interaction between the research team and trainees is vital to the success of the initiative for two reasons. It allows participants to form a consensus about which practices are no longer working and ensures that there is a high level of commitment from participants. These are both key factors in promoting change (Filson and Lewis, 2000; Kettley, 1995). 


\section{FEEDBACK}

The results from the review workshop and questionnaire provided clear indications of the capability of the training initiative to improve design management understanding and practice of a major UK civil and building design and construction company.

\section{A The Handbook}

The reactions of workshop attendees to the handbook were very encouraging. They were asked whether the handbook had a clear and logical format, was easy to read and understand, covered design management in sufficient detail and gave them a good understanding of the subject (Table

2).

\begin{tabular}{|l|c|c|c|c|}
\hline $\begin{array}{l}\text { design } \\
\text { management } \\
\text { handbook... }\end{array}$ & $\begin{array}{l}\text { has a clear and } \\
\text { logical format }\end{array}$ & $\begin{array}{c}\text { is easy to read } \\
\text { and understand }\end{array}$ & $\begin{array}{c}\text { covered design } \\
\text { management in } \\
\text { sufficient detail }\end{array}$ & $\begin{array}{c}\text { gave me a good } \\
\text { understanding of } \\
\text { the subject }\end{array}$ \\
\hline & $\%$ & $\%$ & $\%$ & $\%$ \\
\hline strongly disagree & $0 \%$ & $0 \%$ & $8 \%$ & $0 \%$ \\
\hline disagree & $0 \%$ & $8 \%$ & $17 \%$ & $0 \%$ \\
\hline neutral & $8 \%$ & $17 \%$ & $67 \%$ & $17 \%$ \\
\hline agree & $83 \%$ & $67 \%$ & $8 \%$ & $50 \%$ \\
\hline strongly agree & $8 \%$ & $8 \%$ & & $33 \%$ \\
\hline
\end{tabular}

Table 2: Review of Design Management Handbook

The results suggest that the handbook has a clear and logical format which is easy to read and understand. This is reflected in comments that the 
handbook was well laid out, easy to follow and had a user-friendly approach.

Most respondents considered that the handbook covered design management in sufficient detail. However, some design managers wanted more detail. One stated: "it covers design management well enough for other team members but not for design managers”. The only respondents who did not consider that the handbook gave them a good understanding of design management were two practicing design managers. One believing that after 30 years experience the knowledge required to manage the design process is very difficult to put into a book. However, apart from these criticisms typical comments were that it "helped in understanding design management processes" and provided an "in-depth explanation to help understand issues”.

Very few barriers to implementation were identified, but that different approaches to design management were needed depending on the procurement route and that some tools were not appropriate in all cases. For example, consultant selections tools are not appropriate in the traditional procurement or novated design and build . This was addressed by highlighting the suitability of each tool for design and build, novated design and build and traditional procurement routes in the revised handbook. 
A significant barrier identified during the review was the relatively low position of the design manager within the project team structure. As with much of the current industry approach, design management does not command significant authority within the power structure of a construction project (Heath et al, 1994). Focus remains on the construction activity because it accounts for the majority of the cost of a project, ignoring the potential impact of the design phase on the construction product (Newton, 1995). This illustrates the difficult task of implementing news ways of managing the design process if other project team members are unfamiliar with such methods. However, this also highlights the advantage of the approach taken by this research to educate all staff about design management and not simply design practitioners, an approach endorsed by Baldwin, and Jarrett (2002). As well as helping to break down professional jealousies that can hinder team working (Baldwin, and Jarrett, 2002) it can allow other professionals to understand the importance of design and its impact on procurement and construction phases. 


\begin{tabular}{|c|c|c|}
\hline handbook section & tools provided & training initiative improvement actions \\
\hline 2 The design process & & $\begin{array}{l}\text { Detailed model of design process activities } \\
\text { Structured and explicit design } \\
\text { management process }\end{array}$ \\
\hline $\begin{array}{l}\text { Stakeholders objectives, briefs and } \\
\text { tasks }\end{array}$ & $\begin{array}{ll}\text { P01 } & \text { Brief document } \\
\text { P02 } & \text { Concept design kick-off meeting } \\
\text { P03 } & \text { Scheme design kick-off meeting } \\
\text { P04 } & \text { Detailed design kick-off meeting }\end{array}$ & $\begin{array}{l}\text { Tool to review / check the developed } \\
\text { design will meet stakeholder requirements }\end{array}$ \\
\hline $4 \quad$ Managers and structures & P010 Design manager job description & Detailed design manager job description \\
\hline $5 \quad$ Selecting team members & $\begin{array}{ll}\text { P07 } & \text { Consultant benchmarking } \\
\text { P08 } & \text { Consultant interviews }\end{array}$ & $\begin{array}{l}360 \text { degree performance appraisals for all } \\
\text { project parties supported by database of } \\
\text { benchmarking data. }\end{array}$ \\
\hline 10 Design changes & P05 $\quad$ Design change workshop & $\begin{array}{l}\text { Comprehensive design change } \\
\text { management process }\end{array}$ \\
\hline
\end{tabular}

Table 3: Suggested modifications to the training initiative

Table 3 shows the changes that were requested, mostly for additional tools.

These have been developed since the workshop and included in the revised handbook. In general, the handbook was well received with industrialists finding it user friendly and written in a language that they understand. Also, as the tools were said to be easy to use and aligned with day-to-day activities then it would appear they do not impose any unwanted discipline. Most importantly, the majority of workshop attendees considered that the handbook gave them a better understanding of the design management process. 


\section{The Workshop}

The responses to the training were very encouraging. In the questionnaire respondents were asked whether the context of each module within design management was made clear, the module provided understanding of issues surrounding topic and highlighted practical ways of dealing with issues. The responses are summarised in Tables 4, 5 and 6 respectively.

\begin{tabular}{|l|c|c|c|}
\hline & minimum \% & average \% & maximum \% \\
\hline strongly disagree & $0 \%$ & $0 \%$ & $0 \%$ \\
\hline disagree & $0 \%$ & $1 \%$ & $8 \%$ \\
\hline neutral & $0 \%$ & $5 \%$ & $25 \%$ \\
\hline agree & $33 \%$ & $63 \%$ & $83 \%$ \\
\hline strongly agree & $17 \%$ & $31 \%$ & $42 \%$ \\
\hline
\end{tabular}

Table 4: The context of the training module within design management was made clear

In seven of the ten training modules all respondents were clear about the context of the module within design management. This is probably because the modules were either introductions to design management (Design Management and Design Process) or they related to obvious activities within the process (Stakeholders’ Objectives, Briefs And Tasks, Planning The Design Process, Ensuring Design Delivery, Managing Information Flow, Developing The Design). Some felt the Selecting Team Members module was not clear and that this is an issue normally dealt with by senior management rather than the design manager. Also, many projects in which 
the company are involved follow the traditional or novated design and build procurement route where team member selection happens before the company joins the project team. Therefore, it may not be clear to some how the selection of design team members is part of design management. However, in general, it is clear from the results in Table 5 that the attendees understood the training modules and how the ideas and tools presented apply to the design process.

\begin{tabular}{|l|c|c|c|}
\hline & minimum \% & average \% & maximum \% \\
\hline strongly disagree & $0 \%$ & $0 \%$ & $0 \%$ \\
\hline disagree & $0 \%$ & $1 \%$ & $8 \%$ \\
\hline neutral & $0 \%$ & $4 \%$ & $17 \%$ \\
\hline agree & $58 \%$ & $73 \%$ & $83 \%$ \\
\hline strongly agree & $8 \%$ & $22 \%$ & $42 \%$ \\
\hline
\end{tabular}

Table 5: Training module provided understanding of issues surrounding topic

All Respondents believed that seven of the modules (Design Management, Design Process, Stakeholders’ Objectives, Briefs And Tasks, Planning The Design Process, Ensuring Design Delivery, Managing Information Flow, Developing The Design.) provided an understanding of issues surrounding the topic. Some suggested that Managers And Structures and Selecting Team Members needed more detail. This included additional explanation of organisational structures that support design management; a description of the support available to train design managers and an emphasis that the 
design manager must concentrate on being a manager of the design process and not get too involved in designing. Respondents also felt that the Selecting Team Members module needed further definition: the responsibility and parties involved in consultant selection should be clear and such practices only related to D\&B type procurement routes. These issues have been addressed in the revised handbook and training modules.

It can be concluded that the training provides a good understanding of each design management topic as an average of $95 \%$ of respondents considered this to be the case.

\begin{tabular}{|l|c|c|c|}
\hline & minimum \% & average \% & maximum \% \\
\hline strongly disagree & $0 \%$ & $0 \%$ & $0 \%$ \\
\hline disagree & $0 \%$ & $6 \%$ & $17 \%$ \\
\hline neutral & $17 \%$ & $29 \%$ & $50 \%$ \\
\hline agree & $33 \%$ & $60 \%$ & $83 \%$ \\
\hline strongly agree & $0 \%$ & $5 \%$ & $17 \%$ \\
\hline
\end{tabular}

Table 6: Training module highlighted practical ways of dealing with issues

Five of the training modules (Stakeholders' Objectives, Briefs And Tasks, Ensuring Design Delivery, Selecting Team Members, Managing Information Flow and Developing The Design) were considered to highlight practical ways of dealing with issues. This would be expected, as their focus is the introduction of nineteen of the twenty-five tools. 
However, the majority felt that the tools supporting the Managers And Structure module did not highlight practical ways of dealing with issues. Workshop attendees wanted to see the additions given in Table 3, which have subsequently been added to the revised handbook.

Overall, an average of $65 \%$ of respondents considered that the workshop modules provided practical ways of dealing with issues. If we consider the modules that respondents did not rate highly, two provided an introduction to design management and therefore did not introduce any tools. Secondly, the Managers And Structure module required additional material. Finally, comments suggested that P05 Design Change Workshop introduced in the Design Changes module was insufficiently developed. With these exceptions an average of $74 \%$ considered that the modules highlighted practical ways of dealing with problems and the concerns raised in the workshop and questionnaires have now been addressed in a revised handbook and training material.

Workshop attendees commented that they liked the mix of learning activities (presentation, worked examples, discussion and problem solving) structured into the training modules, making them involved in the training process. However, several people said that they would have liked to see 
more worked examples to help improve their understanding of how to use the tools and their potential benefits.

Other than the above specific issues, there were no fundamental difficulties identified with the training modules and the material they delivered. We therefore conclude that the training modules should provide future attendees with an understanding of how each topic fits into the design management discipline, the issues surrounding design management and practical ways of managing the process.

\section{CONCLUSIONS}

This paper has reported on the development, content and deployment of a design management training initiative within a major UK civil and building design and construction company. This has led to the following conclusions:

1. The design management training initiative provides a sound understanding of the issues surrounding modern design management and practical ways of managing the process.

2. The initiative has the potential to change and improve design management performance within a design and construction organisation as it provides employees with a better understanding of what 
approaches, tools and practices that can help them improve the management of the design process .

3. Design management can be affected significantly by the actions of others, but the design manager is often unable to influence matters due to lack of authority.

4. Any changes to design management practices must involve educating all project parties that interface with the design manager.

5. The position of a design manager within the project team must be comparable to other senior managers to provide the authority which is necessary for the role.

6. Improving design management practice within a design and construction organisation is a long-term activity and must also overcome a range of barriers, not least the underlying company and construction industry culture.

\section{ACKNOWLEDGEMENTS}

The authors would wish to thank Skanska UK Building and the Engineering and Physical Sciences Research Council (EPSRC), which have provided the 
funding for this work through the Centre for Innovative Construction Engineering at Loughborough University. 


\section{REFERENCES}

Austin, S., Baldwin, A., Hammond, J., Murray, M., Root, D., Thomson, D. and Thorpe, A., 2001, Design Chains: A handbook for integrated collaborative design, Thomas Telford, London.

Austin, S., Baldwin, A., Hammond, J. and Waskett, P., 1999, “Application of the Analytical Design Planning Technique in the Project Process” in Proceedings of the Conference on Concurrent Engineering in Construction, VTT, Finland.

Austin, S.A., Baldwin, A.N., Newton, A.J. 1996, “A data flow model to plan and manage the build design process”, Journal of Engineering Design, Vol. 7, No. 1, pp 3-17.

Baldwin, J. and Jarrett, N., 2002, Rethinking Construction - Accelerating Change: Compendium of responses to the consultation paper by the Strategic Forum for Construction, Warwick Manufacturing Group, University of Warwick, UK.

Bibby, L., Austin, S., Bouchlaghem, N., 2002, “Defining an improvement plan to address design management practices: a case study of a UK 
construction company” International Journal of IT in Architecture, Engineering and Construction (IT-AEC), Accepted for publication in early 2003.

Business Round Table, 2002, Teamwork2000 - an experiment in collaborative working, Business Round Table, Kenley, Surrey, UK.

Egan, Sir J., 2002, Accelerating Change: a report by the strategic forum for construction, Rethinking Construction c/o Construction Industry Council. London, UK.

Egan, Sir J., 1998, Rethinking Construction: the report of the construction task force, Department of the Environment, Transport and the regions. London, UK.

Filson, A. and Lewis, A. 2000, "Cultural issues in implementing changes to new product development process in a small to medium sized enterprise (SME)”, Journal of Engineering Design, Vol. 11, No. 2, pp 149-157.

Fellows, R. and Liu, A. 1997, Research Methods for Construction, Blackwell Science, Oxford. 
Freire, J. and Alarcon, L.F. 2000, “Achieving a lean design process” in Proceeding of the $8^{\text {th }}$ International Group for Lean Construction Conference, Brighton, England.

Frost, R.B. 1999, “Why does industry ignore design science”, Journal of Engineering Design, Vol. 10, No. 4, pp 301-304.

Heath, T., Scott, D., Boyland, M. 1994, “A prototype computer based design management tool”, Construction Management and Economics, Vol. 12, pp 543-549.

Kettley, P. 1995, "Is flatter better? Delayering the management hierarchy”, The Institute of Employment Studies, Report 290.

Mohamed, S. 1999, “What do we mean by construction process reengineering?”, International Journal of Computer Integrated Design and Construction, Vol 1, No 2, pp 3-9.

Moore, D.R. and Dainty, A.R.J., 1999, “Work-group communication patterns in design and build project teams: an investigative framework”, Journal of Construction Procurement, Vol 6, No1, pp 44-53. 
Office of Government Commerce, 2002, www.ogc.gov.uk

Newton, A.J. 1995, “The improved planning and management of multi-disciplinary building design”, $P h D$ thesis, Department of Civil and Building Engineering, Loughborough University, Leicestershire.

Race, P. 2001, 2000 Tips for Lecturers, Kogan Page, London.

Thomson, D.S. and Austin, S.A., 2001, “Construction Value Management Revisited: The designer's role” in Proceedings of Cobra 2001 Conference, Glasgow Caledonian University, Glasgow, UK, RICS Foundation. 